\title{
Analysis of the Pesanggem Cognitive Aspects of the Resources Management Program Community Based in Muria Forest
}

\author{
Eva Banowati \\ Geography Departement \\ Social Sciences Faculty \\ Universitas Negeri Semarang \\ Sriyanto \\ Geography Departement \\ Social Sciences Faculty \\ Universitas Negeri Semarang
}

Corresponding email: evabanowatigeografi@mail.unnes.ac.id

\begin{abstract}
The main problem in this research are: 1) how knowledge about the cognitive Pesanggem PHBM program, 2) when invited participation in the implementation of programs that harmonize economic and ecological side. The study population was the whole Pesanggem member Forest Village Community Institution (LMDH). There are two variables in this study, namely: cognitive knowledge and participation, as the control variable is the time and place. Data were analyzed by spatial, among variables tabulated cross-correlation chi-square test. The results obtained are given the knowledge of the cognitive level (C1) to recognize and remember their rights and obligations as Pesanggem who always maintains forest stands; understand (C2), especially the ability to compare the quantity and quality of agricultural production of crops cultivated/planted under forest stands; and the ability to apply (C3) in the choice of plants as growth in forest stands. The third level of cognitive once sat them on the ability to analyze (C4). Invited participation knowledge with the direction of Agricultural Instructor (Suplap PPHBM) to be able to achieve the planned timing of planting C6 especially in the face of change/shift in season or planting calendar. Based on the result of cross tabulation positive relationship exists between cognitive knowledge that is built for the accuracy participation PHBM program implementation. The results of this study showed that the formation of cognition Pesanggem without passing through C5 (evaluation). Upheld from cross check in the field showed that the size of the forest stand grows with age, the production and productivity of agricultural crops normal or comparable with the results. Local knowledge and local knowledge contribute to shaping cognition interact remember in their daily lives affect each other.
\end{abstract}

Keywords-Pesanggem cognitive aspect, participation, forest resources management, community based

\section{INTRODUCTION}

Talks about the need for public education becomes a topic that is often raised in scientific studies, gave birth to a variety of educational realization models packed in empowerment activities that are tailored to the needs of the community and the environment or the community. Indicators of success demonstrated the usefulness of public participation in the implementation of programs that involve them. Retell opinions Isbandi (2007: 27), participation is community participation in the process of identifying the problem and the potential that exists in society, elections and decision-making about alternative solutions to address these problems, the implementation of problem solving, and community involvement in the process of evaluating the changes that occur. Participation in this paper refers to the notion Mikkelsen (1999: 64) serve as a pesanggem community participation in the development of self, life, and environment.

Growing participation in pesanggem influenced by many factors, including education, employment and income, opportunity (Ross, 1967: 130; Holil, 1980: 10). Empirical data and unpublished known successful years of formal education of farmers mostly less than 8 , resulting in their ability to farm stagnant even harder to be upgraded and included in response to the development of the science of farming that affect the quantity and quality of agricultural production is low (Roem, 2013; Banowati, 2016 ).

Education and development needed by the people who work daily pesanggem farmed land Borgan. They can work on Borgan when a member of Forest Village Community Institution (LMDH). Legal entities, has a function as a container forest village communities to establish cooperation with Perum Perhutani in PHBM with the principle of partnership. Education is a process of improving the personal capabilities of adults as members of society, which in turn will increase the capacity of social, economic, and cultural as a learning community investment in lifelong education process more useful. In households living in rural household, which contains educational survival strategy of farming needs to be invested. Including households that are inside and on the edge of the forest area whose numbers tended to increase. In the first decade of the last increase of $4.92 \%$, spread over 21284 
villages around the forest. Although the number of households shifting cultivation was reduced to 17093 (CBS, 2015).

The land area of teak forests in Java Island recorded $1,240,558$ hectares, the number of forest villages in Java and Madura range of 6,000 inhabited around 20-25 million people (one-sixth of the population of the island of Java), who lived in and around the area Perhutani (kabarbisnis.com 2008; Roni, 2012). Alert data from the Ministry Accelerated Development of Disadvantaged Regions (PDT), nationally the percentage of poor families living in forest villages is more than twice the percentage of poor families in Indonesia. Community life has a dependency to the forest, so the existence of an interested party (stakeholders) on the preservation of forests (Banowati, et al., 2015; Banowati, 2016).

Damage to forest resources forests Teak (Tectona grandis) after the reform reached more than $28 \%$ area, Perhutani as state forest managers rolling program Community Based Forest Management (PHBM). The program is implemented by the Decree of the Supervisory Board 136/2001 is a system of management of forest resources carried out jointly by Perum Perhutani and forest village communities as stakeholders with the spirit of sharing that common interest to achieve sustainability of the functions and benefits that can be realized optimally and proportionate, PHBM is a resource forest management by share, which includes shared use of time, space and land, with the principle of mutual benefit, mutually reinforcing and mutually supportive (Banowati and Sriyanto, 2012; Banowati, 2016; Sutejo, 2014: 3). Adhering to the welfare approach (prosperity approach) that put the peasant population pesanggem as Human Resources (HR). They have the integrated capabilities of the overall physical and thinking. Always requires a renewal of the knowledge of cognition or behavior using knowledge to participate conserve forests that can be exploited in a sustainable manner that made the villagebased forest with a scope inside and outside the forest areas both land-based and non-land by considering the scale of priority based on participatory planning. One is through education for the farmers pesanggem. Based on the above arguments in this paper aims to assess the contribution of the cognitive aspects pesanggem participation in program implementation PHBM harmonize both economic and ecological.

\section{METHOD}

The study population was pesanggem farmers LMDH members numbering 851 people on two villages in the Forest Region Muria. Simple sampling techniques for getting the 265pesanggem farmers (Krejcie and Morgan, 1970 in Soegiyono, 2009). Two variables in this study, namely: cognitive knowledge and participation in the implementation of PHBM program, as the control variable is the time (season) and existing land tenure. Data collected by several complementary methods, namely: observation, documentation, interviews. Technique of data analysis is description and analysis of correlation between variables used cross tables.

\section{FINDING AND DISCUSSION}

The study was conducted in two villages in the Forest Region Muria, namely: Semirejo Village - Gembong subdistrict and Dukuhseti village - District of Dukuhseti both villages in Pati Regency Administrative Region. Forest management Teak (Tectona grandis), which serves as production forest can't leave the community role pesanggem, although they are known to depend and rely by utilizing a variety of forest resources by holders of forest management on forest security allegedly as a bully. But not a few people who live around the forest contributes to the preservation of forests. People who have understood the importance of intercropping run of form agricultural activity that supports the resilience of forest land. Community participated in the guarding of the forest looting, despite the theft of stands (forest felling) little by little "can" open/expand agricultural land resulting in reduced stand density/low, only the conditions are not conducive to force the public to explore the forest land.

The scope of the PHBM program inside and outside the forest areas both land-based and non-land by considering the scale of priority based on participatory planning. Implementation was accompanied by field supervisors who continue to give knowledge of forestry and agriculture. Farmers pesanggem respond knowledge appropriate farming experience are built of cognition that is behavior that people acquire knowledge or needed to use the knowledge (Patmonodewo, 2000). The cognitive development shows the development of thinking to solve various problems can be used as a benchmark for the growth of intelligence.

Piaget's theory of cognitive development (1896-1980, in Rifa'i and Anni, 2012: 31) discusses the emergence and obtaining schematics of how one perceives the environment in the developmental stages, when a person obtains a new way of mentally representing information. Four key concept in explaining the cognitive development is a scheme, assimilation, accommodation, and equilibrium. The scheme is to describe the mental and physical actions in the know and understand objects. Assimilation is the process of entering information into a scheme that has been held. Accommodation is the process of changing the scheme which has been owned by the new information. Equilibrium is the balance between the schemes, assimilation and accommodation. Cognitive involves the ability to develop the ability of rational (reason) is one realm in the taxonomy of education (Bloom cited Kuswono, 2012: 6) basic principles of the framework proposed is a way to categorize the intellectual potential consists of phases: knowledge (knowledge), understanding (comprehension), application (user application), analysis (analysis), synthesis (sinthesis), evaluation (evaluation). The cognitive theory emphasizes how a process or an attempt to optimize the ability of rational aspects that are owned by others such as the pesanggem farmers.

Forest communities have the right to cultivate that land with area of 0.25 to 0.5 hectares as the area of intercropping is done to prop up the local economy and ecological forest. Pesanggem farmers in the village of Forest Muria farmed 
understory (PLDT), with the hope of plants understand served to increase the quality of land from a plant that has a root nodule grade Nitrogen $(\mathrm{N})$, and the products of agricultural crops can support the economy. Types and varieties of agricultural crops as directed by Supervisor Courses (Suplap) that is adjusted to the age of stand which refers to the concept of crop rotation, that forest land is maintained fertility and 4 types of agricultural crops suitable cropping calendars produce optimal (Banowati, et al., 2015; Banowati , 2016).

Assistance to pesanggem by Suplap has been conducted from 2015 to 2016 showed a high frequency especially in the third quarter of that when the rainy season. Characteristics of heavy rains with duration uncertain, the long-sometimes rapidly and often did not subside. These conditions need to hang to farmers pesanggem about extreme weather effects of climate shifts/season. In this condition the participation of farmers is more oriented to the rescue of forest land resources, considering this forest spread on Mount Moriah. Forest stands ruled out as vulnerable to collapse.

Pesanggem community participation in PHBM, analyzed based on 5 of 6 levels (level), on level 1 no manipulation is the lowest level of participation and can be categorized as a lack of participation. Further use level 2-6 quoted (Rukmana, 1993, in the Satria, 2015), namely: 2. Dissemination of information where it has been informed about the rights, responsibilities pesanggem; 3. Consultation that allows two-way communication (Pesanggem and Perhutani) through LMDH pesanggem so that people can express their opinions and views, although there is no guarantee that their input is used; 4. Build a deal, that is where the various actors can relate to mutual understanding between one another, negotiate and compromise on various things most accepted by all; 5 . Decision-making, that is where the consensus is generated based on mutual agreement and going on the division of responsibilities between the various actors involved. In this level, the negotiation is done gradually to give agreement to all (Pesanggem and Perhutani) in voicing their aspirations; and the level to 6. Partnership, which is a synergistic relationship between the various actors to achieve mutually agreed objectives. This level, the actors do the division of responsibilities and risks of the consensus that they produce.

TABLE 1. EFFect of Cognitive Pesanggem Against PARTicipation LEVELS

\begin{tabular}{|c|c|c|c|c|c|c|}
\hline \multirow{2}{*}{ Cognitif } & \multicolumn{5}{|c|}{ Level } & \multirow{2}{*}{$\Sigma$} \\
\cline { 2 - 7 } & $\mathbf{2}$ & $\mathbf{3}$ & $\mathbf{4}$ & $\mathbf{5}$ & $\mathbf{6}$ & \\
\hline $\mathbf{C 1}$ & 70 & 83 & 72 & 35 & 5 & 265 \\
\hline $\mathbf{C 2}$ & 62 & 91 & 73 & 22 & 17 & 265 \\
\hline C3 & 72 & 121 & 23 & 10 & 39 & 265 \\
\hline C4 & 102 & 72 & 32 & 33 & 26 & 265 \\
\hline C6 & 58 & 40 & 91 & 44 & 32 & 265 \\
\hline Amount & 364 & 407 & 291 & 144 & 119 & 1325 \\
\hline
\end{tabular}

The results obtained are cognitive aspects at the level of recall $(\mathrm{C} 1)$ to recognize and remember the rights and responsibilities as pesanggem that always maintains the forest stands mostly pesanggem (83) participate in level 3, but the duty forest protection is not optimal, amounting to $51,55 \%$, given the data in 2015 the theft of 97 rods (BKPH Ngarengan, 2016). Stand damage that occurred in the village of Semirejo caused the mountain to the valley wind blowing. Comprehension (C2), especially the ability to compare the quantity and quality of production and productivity of agricultural crops cultivated/planted under forest stands; and the ability to apply (C3) in the selection of plant species as stand growth.

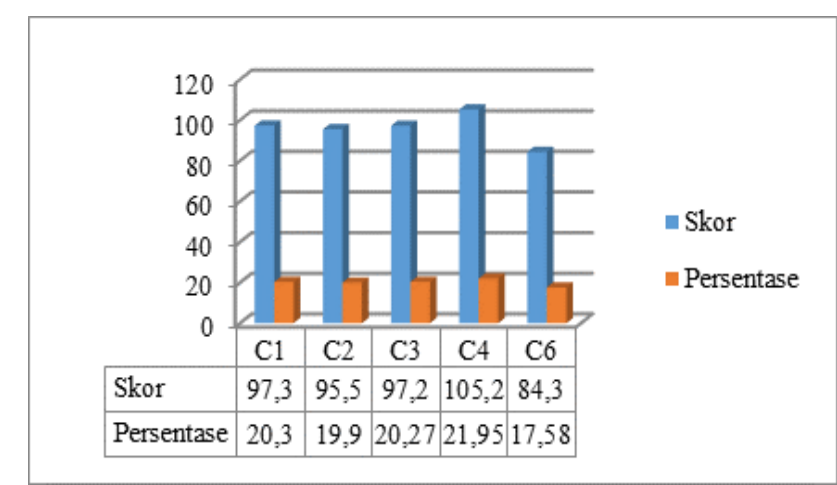

Fig. 1. Score Cognitive Aspects in Implementing PHBM

Source: Primary Data Analysis, 2016

The third cognitive level (C3) in Table 1 once seated them on the ability to analyze (C4) with a total score of 105.2 accounted for $21.95 \%$ participation. The top priority is used to determine the model of education for pesanggem in this study a pilot project demonstration is designed as a medium of learning for farmers pesanggem in the use of forest land correctly with the street replacing cassava with kencur as an accelerated recovery of forest resources to bring harmony between the orientation of interests among stakesholder (Banowati, 2016).

Based on data analysis overall pesanggem communities participate in the implementation of PHBM. Dipartisipasikan knowledge with the direction of Agricultural Extension (Suplap PHBM) to be able to achieve the C6 mainly planned timing of planting/ harvesting in the face of change/shift in season or calendar precision planting/harvesting (Table 2).

Cross tabulation analysis in this study using SPSS 16 showed there/there is a relationship between cognitive knowledge pesanggem farmers against participation in implementing CBFM program is to see the value Asymp Sig (2-Sided) on Chi-Square Test is less than or equal to 0.05 .

TABle 2. CALENDER OF Planting TeAK TREe

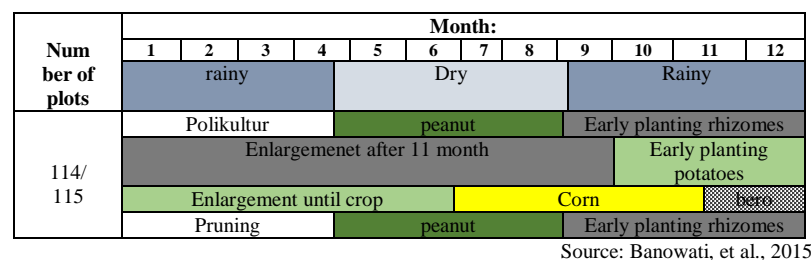


Based on the result of cross tabulation positive relationship exists between cognitive knowledge that is built for the accuracy participation PHBM implementation. The results of this study showed that the formation of cognition pesanggem without passing through C5 (evaluation). Upheld from crossceck field shows that the size of the forest stand grows with age, the production and productivity of agricultural crops normal or comparable with the results.

\section{CONCLUSION AND SUGGESTIONS}

Pesanggem community participation in implementation of PHBM in the Forest Muria farmers affected by cognitive knowledge pesanggem increasingly meet the expectations of the assistance provided by the Supervisor field (Suplap). Farmers pesanggem a human resource as one element of the input (inputs) to produce an output of agricultural products and stands of teak timber or environmental services. As an input, human resources can't be a single element, but must also be combined together with other elements of the acreage, stand age, the type of crops cultivated, and the accuracy of the timing of planting/harvesting.

\section{REFERENCES}

[1] Banowati. Eva, 2011, "Pembangunan Sumberdaya Hutan Berbasis Masyarakat Pada Kawasan Hutan Muria," Disertasi. Yogyakarta: Fakultas Geografi Universitas Gadjah Mada.

[2] Banowati. Eva dan Sriyanto, 2012, "Geografi Pertanian," Yogyakarta: Ombak.

[3] Banowati. Eva, Indrayati. Dyah Rini, Sunyoto, 2015, "Pengembangan Model PLDT Untuk Pengentasan Kemiskinan dan Realisasi Ketahanan Pangan di Kabupaten Pati," Laporan Penelitian Stragnas, Semarang: UNNES.

[4] Banowati. Eva, 2016, "Pemberdayaan Penduduk Pesanggem Untuk Pengentasan Kemiskinan dan Percepatan Pemulihan Sumberdaya Hutan Muria," Jurnal Spatial Vol. 16 No. 2 Tahun 2016, Jakarta: Universitas Negeri Jakarta.

[5] BKPH Ngarengan, 2015, "Data Keamanan BKPH Ngarengan dalam Bulan Agustus s/d Desember 2015,".

[6] BPS, 2015, "Analisis Rumah Tangga Usaha Bidang Kehutanan dan Rumah Tangga Sekitar Hutan," Jakarta: Badan Pusat Statistik.

[7] Dephutbun, 1999, "Undang-Undang No. 41 Tahun 1999," Jakarta: Dephutbun
[8] Holil Soelaiman, 1980, "Partisipasi Sosial dalam Usaha Kesejahteraan Sosial," Bandung.

[9] Isbandi Rukminto Adi, 2007, "Perencanaan Partisipatoris Berbasis Aset Komunitas: dari Pemikiran Menuju Penerapan," Depok: FISIP UI Press.

[10]Mikkelsen. Britha, 1999, "Metode Penelitian Partisipatoris dan Upaya-upaya Pemberdayaan: sebuah buku pegangan bagi para praktisi lapangan," Jakarta: Yayasan Obor Indonesia.

[11] Kabarbisnis.com, 2010, "Potensi Ekonomi Masyarakat Desa Hutan Tak Dimaksimalkan'" Artikel on line, Diunggah 30 September 2010, diunduh 11 Oktober 2016.

[12] Kuswono. Wowo Sunaryo, 2012, "Taksonomi Kognitif," Bandung: PT Remaja Rosdakarya.

[13] Patmonodewo. Soemitra, 2000, "Pendidikan Anak Prasekolah,” Jakarta: Rineka Cipta.

[14]Perhutani, 2001, "Keputusan Ketua Dewan Pengawas Perum Perhutani tentang Pengelolaan Sumberdaya Hutan Bersama Masyarakat," Jakarta: Perum Perhutani.

[15] Rifa'i. Achmad dan Catharina Tri Anni, 2012, "Psikologi Pendidikan," Semarang: Unnes Press.

[16] Roem. M, 2013, "Pendidikan Petani Rendah Pengaruhi Produksi Pertanian," Artikel on line, Diunggah 27 Maret 2013, diunduh 11 Oktober 2016.

[17] Roni, 2012, "Kehutanan," Artikel on line, Diunggah 02 Januari 2012, diunduh 11 Oktober 2016.

[18] Ross, Murray G, and B,W, Lappin, 1967, "Community Organization: theory, principles and practice," Second Edition. NewYork: Harper \& Row Publishers.

[19] Rukmana, D,W,Nana, 1993, "Manajemen Pembangunan Prasarana Kota," Jakarta: LP3S.

[20] Satria, Ase, 2015, "Teori Partisipasi: Pembagian Tingkat Partisipasi Masyarakat Dalam Proses Pembangunan," Artikel on line, diunggah 2015, diunduh 18 Oktober 2016.

[21] Sugiyono, 2009, "Statistika untuk Penelitian," Bandung: CV Alfabeta.

[22] Sutejo. Probo, 2014, "Hubungan Program Pengelolaan Hutan Bersama Masyarakat Terhadap Peningkatan Pendapatan Masyarakat," Jurnal Ilmiah Pendidikan Geografi, Semarang: IKIP Veteran Semarang. 